\title{
MORPHOMETRIC ANALYSIS OF SEAGRASSES SPECIES IN NEGROS ORIENTAL
}

\author{
${ }^{1)}$ Billy Th. Wagey \\ ${ }^{1)}$ Marine Biology laboratory, Faculty of Fisheries and Marine Science Sam Ratulangi University \\ J1. Kampus Unsrat Manado 95115 \\ e-mail: bwagey@yahoo.com
}

\begin{abstract}
ABSTRAK
Studi variasi morfometrik dari 5 spesies lamun di Negros Oriental Philippines dilaksanakan pada bulan Januari sampai Maret 2011. Pengukuran variable morfologi yang diambil adalah: panjang akar, tinggi tegakkan lamun, panjang daun terpanjang dalam $\mathrm{cm}$. Hasil studi menunjukkan: 1) Species Lamun yang diperoleh dari daerah Bais memiliki ukuran terkecil sedangkan lamun yang berasal dari Banilad yang tertinggi; 2) Diantara semua spesies yang teramati, Cymodocea rotundata tidak menunjukkan variasi morfometrik
\end{abstract}

Kata Kunci: morfometrik, akar, daun terpanjang

\section{ANALISIS MORFOMETRIK SPESIES LAMUN DI NEGROS ORIENTAL}

\begin{abstract}
A study of morphometric variations of five seagrass species in Negros Oriental, the Philippines was conducted from January to March 20011. Measurements of the following morphological variables were taken: length of rhizomes, length of upright shoot, length of longest leaf $(\mathrm{cm})$. The study showed that: 1) Seagrass species from Bais had the lowest size range in morphometric measurements, whereas those from Banilad had the highest; 2) Among all the species observed, Cymodocea serrulata did not show morphometric variations.
\end{abstract}

Keywords: morphometric, rhizome, longest leaf

\section{INTRODUCTION}

Seagrasses are angiosperms that are related to terrestrial flowering plants. They are living partially or entirely submerged in marine waters. They have erect leaves, buried root-like structure (rhizomes) that hold the plants in the sediments, and roots that take up nutrients from sediments for growth. As a result, seagrasses are not a taxonomically unified group but a 'biological' or 'ecological' group. The evolutionary adaptations required for survival in the marine environment have led to convergence in morphology.

Seagrasses are interesting because they form long-lived, structurally-complex benthic communities. Seagrasses are highly diverse. There are about 60 known seagrass species in the world, 13 of which has been recorded in Philippine waters. Because of this high diversity, there has recently been an expanding interest in evaluating various morphometric structural and dynamic parameters in seagrasses.

In response, the study aims to assess morphometric variation among 5 seagrass species in dominant coastal seagrass habitats representing 3 environment types (pristine, moderately disturbed, and intensely disturbed) in Negros Oriental Province, Philippines.

\section{MATERIALS AND METHOD}

\section{Sampling and Study Sites}

Sampling was carried out from January to March 2007 at selected locations in the seagrass beds area of Bais-Talabong, Bacong-Banilad, and Dumaguete-Bantayan (Fig.1).

- Transect quadrat sampling was performed using $100 \mathrm{~m}$ transect and ten quadrats per transect $(25 \mathrm{~cm} \times 25 \mathrm{~cm})$.

- Samples were rinsed carefully to remove sediments using seawater ensuring the 
short-shoots remained attached to the rhizomes.

- Samples were placed in labelled plastic bags and kept into the refrigerator for subsequent morphometric analysis.

- Measurements of the following morphological variables were taken: length of rhizomes, length of upright shoot, length of longest leaf $(\mathrm{cm})$, number of leaves, number of nodes, and the present of flower and fruit.

- $\quad$ ANOVA single factor followed by SNK and T-test were used to analyze morphometric variation.

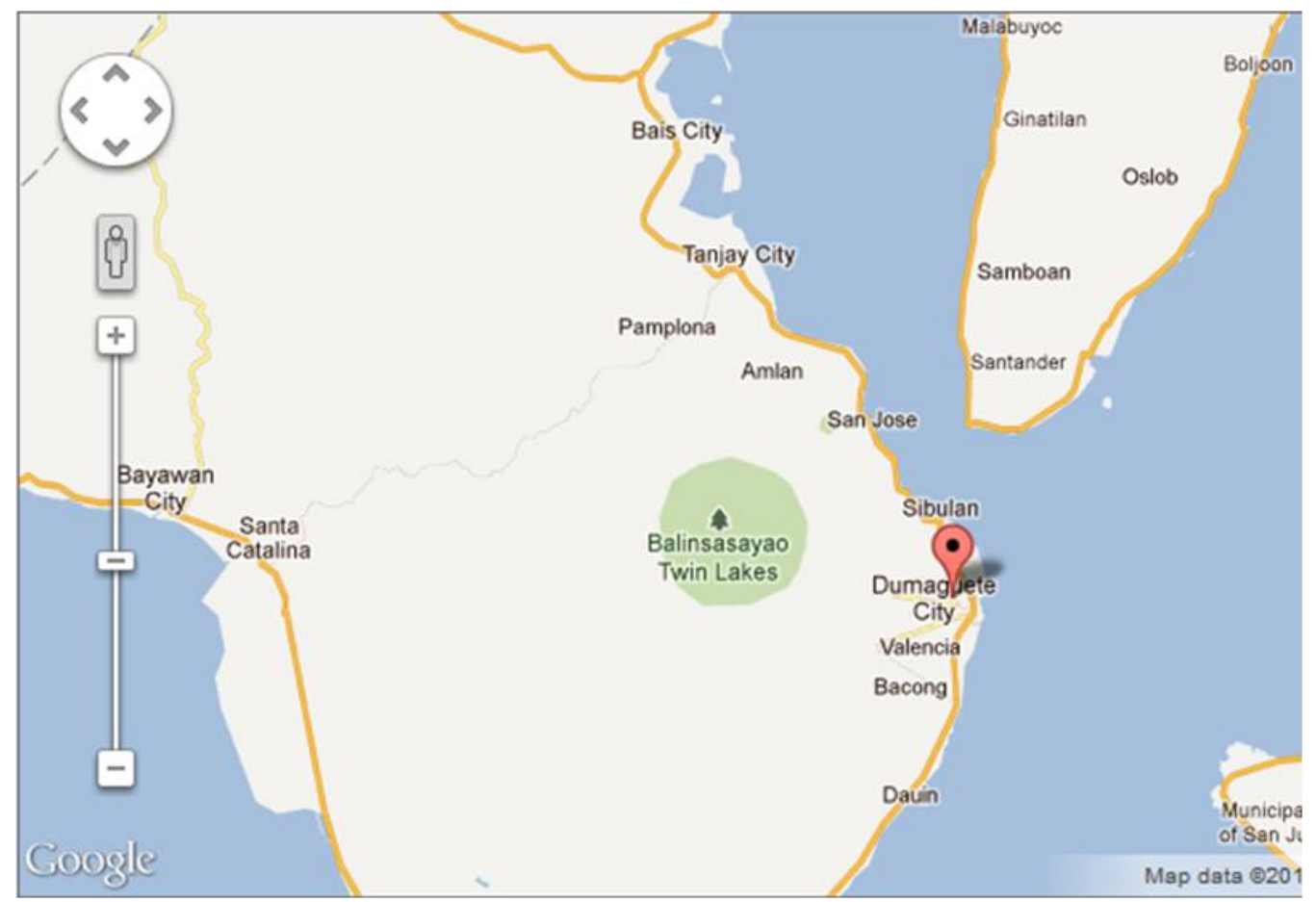

Figure 01. Study site.

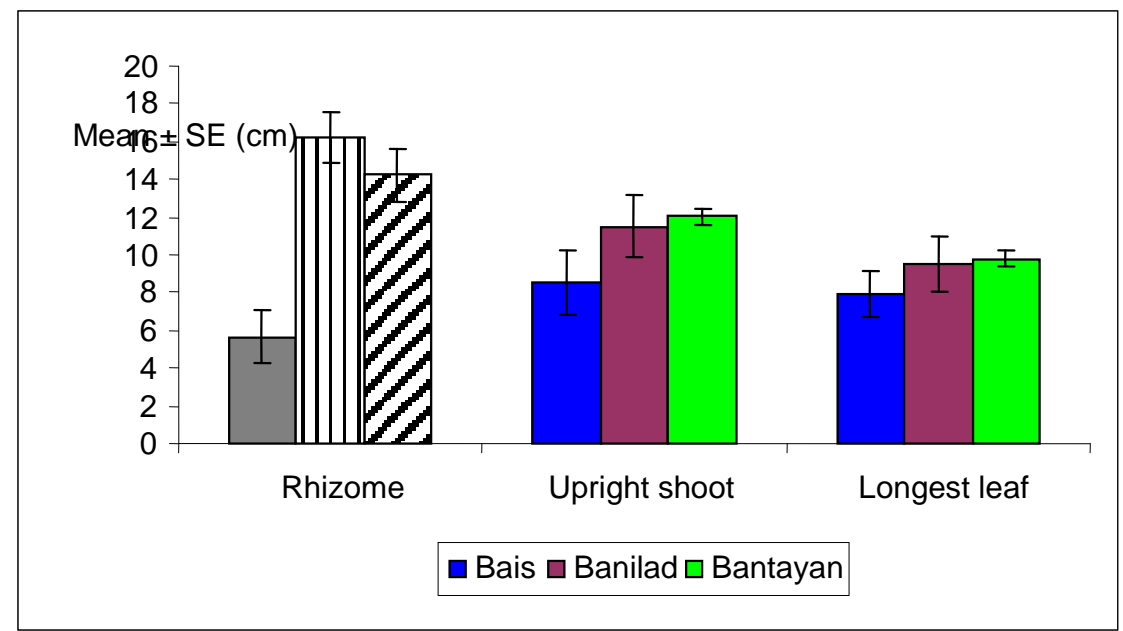

Figure 2. A comparison of the mean total length of rhizomes, upright shoot and longest leaf of Thalassia hemprichii (Ehrenberg) Ascherson.

\section{RESULT AND DISCUSSION}

ANOVA single factor revealed that in terms of mean total length of rhizome,
Thalassia in Bais is significantly different than those of in Banilad and bais. On the other hand there is no significant difference 
between the total mean length of rhizome of Thalassia in Banilad and Bantayan (Fig. 2 and Table.1). Although, the mean total length of the longest leaf of Thalassia was not significantly different in all sites, the upright shoot showed significant difference.

It has been reported that exposure to high temperature would affect the growth of
Thalassia negatively (Tussenbroek et al., 2005). Bais beds were exposed during low tides which probably explains why Thalassia in this area have shorter rhizome and upright shoot

Table 1. ANOVA of the mean total length of rhizomes, upright shoot and the longest leaf of Thalassia hemprichii (Ehrenberg) Ascherson.

\begin{tabular}{|c|c|c|c|}
\hline & F & Probability & SNK \\
\hline Rhizome & $\mathbf{F}=\mathbf{9 . 4 2 2 9 0 9}$ & $\mathbf{P}=\mathbf{0 . 0 0 0 6 6 7}$ & Bais $<$ Banilad = Bantayan \\
\hline Upright* shoot & $\mathbf{F}=\mathbf{5 . 4 8 3 2 1 2}$ & $\mathbf{P}=\mathbf{0 . 0 9 1 4 4}$ & Bais $<$ Banilad = Bantayan \\
\hline Longest leaf* & $\mathbf{F}=\mathbf{0 . 8 5 5 1 6}$ & $\mathbf{P}=\mathbf{0 . 4 3 8 9 7 3}$ & No significant difference \\
\hline
\end{tabular}

Table 2. ANOVA of the mean total length of rhizomes, upright shoot and the longest leaf of Halophila ovalis (R.Brown) Hooker $\mathrm{f}$.

\begin{tabular}{|c|c|c|c|}
\hline & F & Probability & SNK \\
\hline Rhizome* $^{*}$ & $\mathrm{~F}=2.379573$ & $\mathrm{P}=0.102059$ & No significant difference \\
\hline Upright shoot $^{*}$ & $\mathrm{~F}=27.88653$ & $\mathrm{P}=0.0000000$ & Bais=Bantayan<Banilad \\
\hline Longest leaf* & $\mathrm{F}=20.39488$ & $\mathrm{P}=0.0000000$ & Bais $<$ Bantayan<Banilad \\
\hline
\end{tabular}

Species of Halophila showed different performance due to environmental condition. In term of Rhizome, this species it seems to adapt well with different substrate of seabed. There was no significant difference was found in all sites (Fig. 3 table 2). On the contrary, this species was change in morphological of leaf and shoot. The leaf and shoot were found shorter in Bais than in others. This can be assumed that due to low light intensity for the seabed in Bais is covered mostly by mud and silt which is produce a high turbidity that prevent the light penetrate to the seawater hence the leaf cannot grow larger.

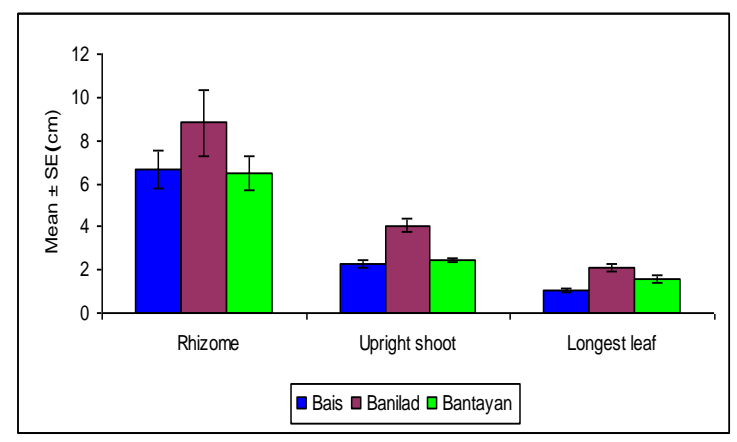

Figure 3. A comparison of the mean total length of rhizomes, upright shoot and the longest leaf of Halophila ovalis (R. Brown) Hooker $\mathrm{f}$

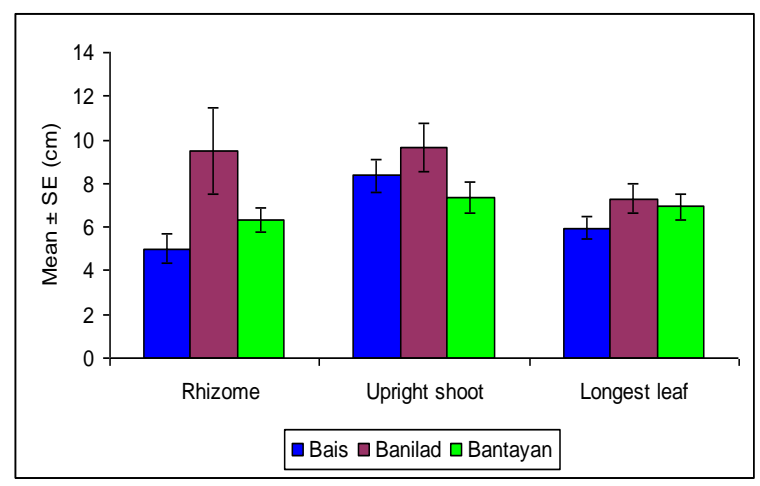

Figure 4. A comparison of the mean total length of rhizomes, upright shoot and the longest leaf of Halodule uninervis Forkskăl Ascherson

Figure 4 and table 3 showed that only the mean total of Rhizome was significantly low in Bais whereas the upright shoot and the leaf were not significant difference in all sites. This phenomenon was a consequence of the morphological adaptation due to the highly exposed at low tide in Bais. 
Table 3. ANOVA of the mean total length of rhizomes, upright shoot and the longest leaf of Halodule uninervis (Forsskăl) Ascherson

\begin{tabular}{|l|l|l|l|}
\hline & \multicolumn{1}{|c|}{$\mathbf{F}$} & \multicolumn{1}{|c|}{ Probability } & \multicolumn{1}{c|}{ SNK } \\
\hline Rhizome* $^{*}$ & $\mathrm{~F}=\mathbf{3 . 7 3 7 2 0 3}$ & $\mathbf{P}=\mathbf{0 . 0 3 5 5 4 7}$ & Bais=Bantayan<Banilad \\
\hline Upright shoot* $^{\mathrm{F}=\mathbf{2 . 7 4 9 5 3 2}}$ & $\mathbf{P}=\mathbf{0 . 7 3 0 9 1}$ & No significant difference \\
\hline Longest leaf & $\mathrm{F}=\mathbf{1 . 4 0 0 8 4 8}$ & $\mathbf{P}=\mathbf{0 . 2 6 2 0 4 4}$ & No significant difference \\
\hline
\end{tabular}

Table 4. T-tests of the rhizome, upright shoot, and longest leaf of Syringodium isoetifolium (Ascherson) Dandy.

\begin{tabular}{|c|c|c|c|}
\hline & T-stat & Probability & Results \\
\hline Rhizome* $^{*}$ & $\mathbf{2 . 1 5 4 2 6 2}$ & $\mathbf{0 . 0 3 2 6 8 8}$ & Banilad > Bantayan \\
\hline Upright shoot* $^{*}$ & $\mathbf{5 . 1 0 1 8 7 3}$ & $\mathbf{9 . 2 1 E - 0 7}$ & Banilad > Bantayan \\
\hline Longest leaf & $\mathbf{5 . 0 2 6 5 4 6}$ & $1.3 E-06$ & Banilad > Bantayan \\
\hline
\end{tabular}

Table 5. T-test of the rhizome, upright shoot, and longest leaf of Cymodocea serrulata (R.Brown) Ascherson and Magnus.

\begin{tabular}{|c|c|c|c|}
\hline & T-stat & Probability & results \\
\hline Rhizome & $\mathbf{0 . 5 0 4 7 7 5}$ & $\mathbf{0 . 6 1 5 9 7 9}$ & No significant difference \\
\hline Upright shoot & $\mathbf{0 . 0 7 3 3 9 3}$ & $\mathbf{0 . 9 4 1 7 9 8}$ & No significant difference \\
\hline Longest leaf & $\mathbf{0 . 4 6 3 0 4 4}$ & $\mathbf{0 . 6 4 5 3 8 3}$ & No significant difference \\
\hline
\end{tabular}

T-test analysis showed that the total means of rhizome, upright shoot, and longest leaf of Syringodium were significantly higher in Banilad than those in Bantayan (Fig. 5 table 4). It can be implied that the environmental condition in Banilad site promotes better growth of the seagrass species.

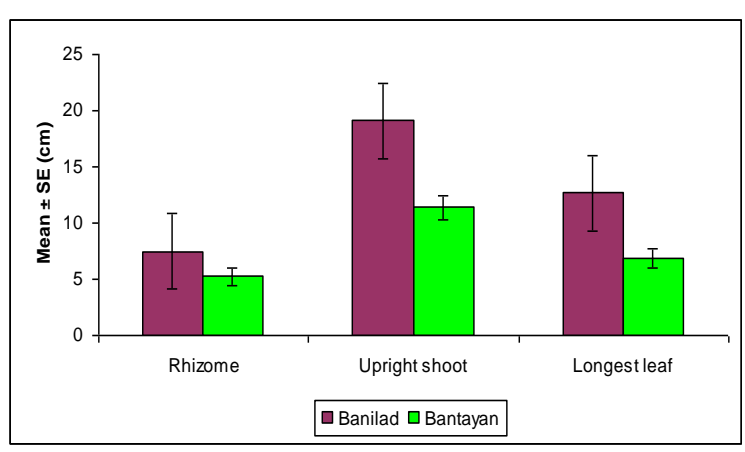

Figure 5. A comparison of the mean total length of rhizomes, upright shoot and the longest leaf of Syringodium isoetifolium (Ascherson) Dandy

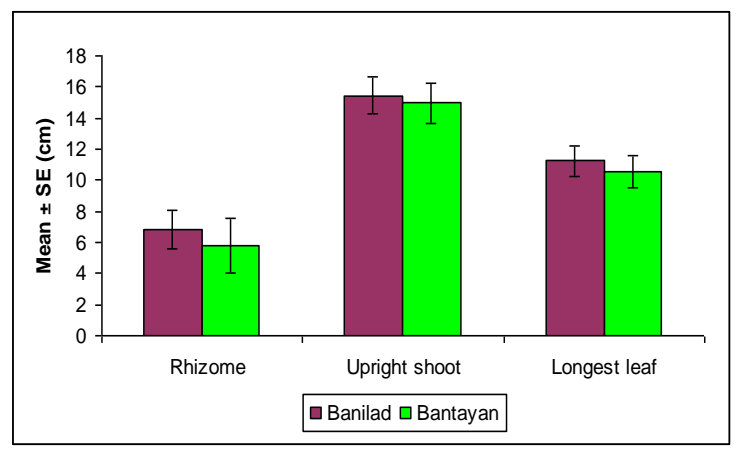

Figure 6. A comparison of the mean total length of rhizomes, upright shoot and the longest leaf of Cymodocea serrulata (R.Brown) Ascherson and Magnus.

T- test analysis showed there is no significant difference of morphometric measurement found in all sites (Fig. 6 Table 5). It can be assumed that Cymodocea serrulata can well adapt in different environmental conditions. 


\section{CONCLUSION}

- Seagrass species from Bais had the lowest size range in morphometric measurements, whereas those from Banilad had the highest.

- Among all the species observed, Cymodocea serrulata did not show morphometric variations.

\section{ACKNOWLEDGMENT}

Special Thanks to Dr. Calumpong for her professional comments on the earlier version of this paper, and to editors and reviewers Dr. Janet Estacion, Rio Naguit and Dioli who made further valuable and constructive suggestions on this paper. Thanks to graduate collogues Francis Argente and Julius for data collection, and to sir Roy de Leon for data analysis and computer assistance.

\section{REFERENCES}

Calumpong HP, Meňez EG. 1997. Field guide to the common mangroves, seagrasses and Algae of the Philippines. Bookmark, Makati City, Philippines. 197 pp.
Kuo J and McComb AJ. 1989. Seagrass taxonomy, structure and development. In: AWD Larkum et al. (eds). Biology of seagrass. Elsevier, Amsterdam. pp 6-73

Van Tussenbroek BI, Vonk JA, Erftemeijer PLA, Middleburg JJ, and Zieman JC. 2005. The Biology of Thalassia: Paradigms and recent advances in research. In: AWD Larkum, RJ Orth and CM Duarte (eds). Seagrasses: Biology, ecology and conservation. Dordrecht, Springer. Netherland. pp 1-31

Waycott M, Kathryn Mc Mahon, Jane Mellors, Ainsley Calladine and Diana Kleine. 2004. A guide to tropical seagrasses of the Indo-west Pacific. James Cook University, Townsville. $72 \mathrm{pp}$.

Waycott M, Procaccini G, Les DH and Reusch TBH. 2006. Chapter 2 Seagrass evolution, ecology and conservation: a genetic perspective. In: AWD Larkum, RJ Orth and CM Duarte (eds) Seagrasses: Biology, ecology and conservation. Dordrecht, Springer. Netherland. 